with a new glow. Is there any joy of service to be compared with that of the investigator who has wrung a new secret from the heart of nature, listening when she has whispered a single syllable of truth unuttered before, who has been able to add a single stone to the great temple of learning, the noblest of all the structures ever reared by man? Is there any more religious calling than thus thinking God's thoughts after him, and proclaiming the gospel of truth to confirm faith, prevent illness, deepen self-knowledge and that of society, industry, give us mastery over the physical, chemical, biological energies that control the world, and develop mathematics, the language of all who think exactly, a language which all sciences tend to speak in proportion as they become complete? This is why research is religious and the knowledge gained in the laboratory to-day may set free energies that benefit the whole race to-morrow. Is not an institution devoted, heart and soul, to this sort of "work, the best thing any community can have in its midst, and should it not be cherished as the heart of this "Heart of the Commonwealth"?

\section{G. Stanley Hall}

\section{ClaAk University}

\section{RUSSTAN VERSUS AMERICAN SEALING1}

IN recent discussions of matters relating to the fur seals of the Pribilof Islands great stress has been laid in certain quarters upon the similarity between the recent crisis in the herd's condition and a crisis in which it found itself in 1834, during Russian control. Since 1896 pelagic sealing has been looked upon by the majority of those having to do with the herd as the sole cause of its decline. But in 1834 and prior to that time there was no pelagic sealing, only land sealing. The argument, has, therefore, been that land sealing was common to both crises and hence a probable cause of decline in one as well as in the other.

Land sealing as practised upon the islands

1 Presented at the forty-fourth annual meeting of the American Fisheries Society in Washington, D. C., September 30-October 3, 1914. since 1868 , when the herd came into the possession of the United States, has consisted in the taking of the superfiuous young male seals at or about the age of three years, the fur seal being polygamous and its handling being analogous to that of the commoner domestic animals. Pelagic sealing was an indiscriminate form of sealing, conducted in the open sea, while the animals were on their winter migration in the Pacific Ocean or on their summer feeding excursions in Bering Sea, both of which take them far from land. Investigations of the pelagic catch show conclusively that sixty-five to eighty-five per cent. of the animals taken have been gravid or nursing females, with which died their unborn or dependent young.

There can be no dispute regarding these two forms of sealing, as they have been conducted, at least since the beginning of pelagic sealing, about the year 1880; the records are exact and complete. The question therefore turns upon the nature of Russian sealing at and prior to 1834, of which the records are not so complete.

In the debates in congress upon the fur-seal law of 1912, in which land sealing was suspended, as a measure necessary for the protection and preservation of the herd, Senator Shively, of Indiana, made the principal speech in the Senate, taking as his thesis the assertion that the Russians never killed anything but bachelor seals. Representative Goodwin, of Arkansas, made the leading speech in the House and his thesis was that the Russians did not kill female seals. These speeches were alleged to have been based upon the official records of Russian operations. Their purpose was to show that the Russian sealing, which was followed by the disaster of 1834 , was identical with that conducted on land by the United States in the disastrous period culminating in 1911, that is-confined to the bachelor seals or superfluous males.

Our knowledge of Russian conditions is derived exclusively from the writings of Bishop Ivan Veniaminof, a Greek-Russian priest, located for the period in question at Unalaska, and a brief extract from the report of an agent of the Russian government, Yanovsky 
by name, who made a special investigation of the seal herd in 1820. Bishop' Veniaminof's account of the seals was published at St. Petersburg, in 1842, in a work known as the "Zapiski," and comprises pages 349 to 381 of volume 2 of that work. A partial translation of this article has been in existence for some time as an appendix to the fur-seal monograph of Henry W. Elliott, published in 1881, as part of the tenth census. Recently there has been made a complete and more accurate translation, by Professor Raphael Zon, of the U. S. Forest Service, which appears as an appendix to a report on the fur:seal herd by the writer to the U. S. Bureau of Fisheries for 1912, as yet unpublished. It is from this translation the quotations which are to follow are made.

The extract from the report of Yanovsky appears in a letter from the Board of Administration, of the Russian-American Company, dated at St. Petersburg, March 15, 1821, and constitutes Letter 6 in the volume of facsimiles in the proceedings of the Paris Tribunal of Arbitration of 1893. A translation of the letter appears at page 58 of volume 2 of the same proceedings in an appendix to the case of the United States. This translation is paralleled by a British version at page 323 of volume 8 of the proceedings, being a part of the British counter case.

These translations of Yanovsky's report differ in one important particular and the essential part may be here reproduced in parallel columns for comparison. The translations are as follows:

\section{American Version}

Every year a greater number of young bachelor seals is being killed, while for propagation there remain only the females, sekatch, and half sekatch. Consequently only the old breeding animals remain, and if any of the young breeders are not killed by autumn, they are sure to be killed in the following spring.
The difference obviously lies in the use of word "bachelors" instead of "young breeders," in the British version. Accepting this translation the criticism of Yanovsky is that too many bachelor seals were being killed and hence the decline of the herd.

A study of the context, however, readily shows that the word translated "bachelors" in one case and "young breeders" in the other is contrasted with "old breeding animals" in the one case, "old seals" in the other. Internal evidence therefore favors the American translation-“young breeders." This translation is not in itself a logical one, since the animals under consideration are not "breeders" at all, but animals which have not yet attained breeding age. Mr. M. Lippitt Larkin, a Russian scholar, formerly instructor in Stanford University, in translating this letter, has pointed out the fact that, since the Russian, like English, is deficient in a feminine form for the word " holostiaki," here translated "bachelors," the plural might reasonably be taken to cover both sexes, as "men," in phrases like "the children of men," in English, is understood to include both sexes. $\mathrm{He}$ suggests that "unmated animals," both sexes being understood, would be a possible, even preferable, translation. If no other light on the question existed than is contained in the letter itself, it would not be necessary to accept the narrow translation of "bachelors" used in the British text.

Fortunately, however, we do not have to depend solely upon the letter itself. The report of Yanovsky was made to the Russian authorities at St. Petersburg. The letter, giving its gist, is one addressed the following spring, that is, in 1821, to the administrator of the Russian-American Company on the seal islands, for his information and instruction. In the article of Bishop Veniaminof, page 369, we find this statement as translated by Professor Zon:

Only in 1822 Muraview, the head administrator, ordered to leave every year young seals for breeding.

The head administrator did not order "bachelors" left, but "young seals," which 
includes both sexes. We have a right to assume that this order was an intelligent interpretation of Yanovsky's recommendation. He had reported that the young seals were too closely killed; the order was that a reserve of such animals should be set aside for breeding purposes.

It may be noted, therefore, that the testimony of the Russian agent Yanovsky is that in the period at and prior to 1820 the Russians were killing young female seals.

The statements of Bishop Veniaminof are much more detailed and definite. In the Zon translation from page 353 of the Zapiski, we read:

Under the name Kotiki, or gray pups, are classed the four-months-old males and females, which were born in the spring and which form the largest and almost the entire quantity of seals used in the trade.

This means that the Russian sealing took chiefly the gray pups at the age of four months, male and female alike. Amplifying this idea further, we may continue to quote from page 360 :

Some years in September the young pups form large pods and congregate in special places and lie carelessly, so that they all can be driven off without leaving a single one behind. Such pods are very advantageous for the trade but are the most ruinous for the increase of the herd.

The reason for this is made plain on page 364. After describing at considerable length the Russian method of driving and sorting the seals, which was from the breeding grounds and included all classes of animals, he concludes with these words:

As soon as they are rested the killing is begun with clubs. Small pups which were born the same summer are killed without discrimination, both males and females.

These are very positive statements and there can be no doubt about the translation. They confirm the statement of Yanovsky that the Russians killed the young seals too closely, leaving only the "old breeding animals" for propagation. As these older animals died off in the course of time through natural termi- nation of life, the herd necessarily declined. The account of Veniaminof adds other details of importance, among them that the general oversight and control exercised by the Russians was inadequate. He says, page 368 :

From the very discovery of the Pribilof Islands (1786) until $1805 \ldots$ the industry on both islands was carried on without any plan, because at that time there were many companies and therefore many masters and each of them attempted to kill as many seals as possible.

As a result of this it was necessary to cease killing for a time, but the irresponsible methods were not reformed and so Veniaminof continues:

From the time of those close seasons, that is on the island of St. George from the year 1808 and on the island of St. Paul from 1810 to 1822, killing was carried on on both islands without any economy and even with extreme negligence, so that even sikatchi (adult bulls) were killed for their skins and mother seals perished by the hundreds in the drives and in their journeys from the breeding grounds to the slaughtering places.

This is from page 369 . Then came the order of Muraviev, already cited, following the report of Yanovsky-to save young seals for breeding. Even this order was disregarded, as we learn from page 371, where Veniaminof tells us,

It was ordered that more care should be exercised in separating adult and young females from the seals which were being killed, and to try as far as possible to reserve some of those which would regularly be killed.

These are the Russian records in so far as they are available to us. They show that Russian sealing was not confined to the bachelors, as is the land sealing of to-day and that it included females as well as males.

This was all prior to 1834 . The efforts toward reform of these early methods failed, one after another, because they were directed toward limitation or suspension of all killing for brief periods and not toward the elimination of indiscriminate killing. With the crisis of 1834 came a complete change in Russian methods. Prior to that time the driving had 
been from the breeding grounds, old and young, males and females, being subjected to the strain of the process, the lack of proper oversight and care, rendering it destructive in the extreme. Adult females, young females and female pups were regularly killed. The driving was now limited to the hauling grounds, frequented only by the bachelors, or joung immature males, and these animals alone were killed. The females, adult and young, were everywhere protected from driving and from killing. This was the condition of the industry at the time it passed into American control in 1868. The depleted herd of 1834 had been restored to a maximum condition of growth and for twenty years thereafter it yielded a fixed product of one hundred thousand skins annually.

That it has not continued to yield this product was due simply to the fact that there developed, after the year 1880, a new industry carried on at sea, which by 1894 had exceeded in its annual catch the maximum product taken on land. Indiscriminate in its nature, that is, including the females as well as the males and causing the destruction of the unborn and dependent young, male and female alike, the effect of pelagic sealing was necessarily to throw the herd again into decline and in the end to bring it to a state of collapse similar to that experienced in 1834 . Neither land sealing as such nor pelagic sealing as such was the cause of this. It was due solely to the killing of females. Just prior to 1911 the killing of females occurred in the sea in connection with pelagic sealing. Prior to 1834 it occurred on land in connection with the undeveloped and unperfected Russian land methods.

As the cessation of the killing of females by the Russians after 1834 stayed the herd's decline and provided amply for its recuperation, so the suspension of pelagic sealing, effected by the treaty of July 7, 1911, is an adequate remedy for the recent decline in the herd and a guarantee for its restoration and future protection.

The suspension of land sealing, incorporated in the law giving effect to this treaty of 1911, was a wholly unnecessary measure-wasteful in the extreme, and certain in the end to be harmful to the breeding life of the herd.

George Archibald Clark

\section{SCIENTIFIC NOTES AND NEWS}

Dr. August Weismann, professor of zoology at Freiburg since 1867, died on November 6, at the age of eighty years.

THE twenty-third annual meeting of the American Psychological Association will be held in affliation with the American Association for the Advancement of Science, the American Society of Naturalists and the Southern Society for Philosophy and Psychology at the University of Pennsylvania, Philadelphia, Pa., on December 29, 30 and 31. Professor R, S. Woodworth, of Columbia University, is the president and Professor R. M. Ogden, of the University of Kansas, is the secretary.

The American Phytopathological Society has selected the Hotel Walton as headquarters during its meeting in Philadelphia, December 29 to January 1. Members should make their reservations at once. Material for the pathological exhibition may be forwarded in care of Dr. Allen J. Smith, Room 214, Medical Building, University of Pennsylvania.

Martin G. Brumbaugh, Ph.D. (Pennsylvania), governor-elect of the state of Pennsylvania, was professor of pedagogy in the University of Pennsylvania from 1895 to 1900 and from 1902 to 1906 , since when he has been superintendent of schools for Philadelphia.

$\Delta \mathrm{T}$ the meeting of the Association of Amerian Universities at Princeton University, on November 7, President George E. Vincent, of the University of Minnesota, was elected president; President Arthur T. Hadley, of Yale, vice-president, and Provost Edgar Fahs Smith, of the University of Pennsylvania, secretary. President John Grier Hibben, of Princeton, and President Thomas H. McBride, of the University of Iowa, were elected to the executive committee.

Aт the meeting of the Association of State University Presidents in Washington last week, President Benjamin Ide Wheeler, of the 